Check for updates

Cite this: RSC Adv., 2019, 9, 32232

Received 25th May 2019

Accepted 27th September 2019

DOI: $10.1039 / c 9 r a 03956 b$

rsc.li/rsc-advances

\section{The effects of $\mathrm{Bi}_{2} \mathrm{O}_{3}$ on the selective catalytic reduction of $\mathrm{NO}$ by propylene over $\mathrm{CO}_{3} \mathrm{O}_{4}$ nanoplates}

\begin{abstract}
Dezhong Yu, (D) ${ }^{a}$ Xin Zhong, ${ }^{a}$ Dong Liu (D) *a and Ying Liang ${ }^{b}$
$\mathrm{Bi}_{2} \mathrm{O}_{3} / \mathrm{CO}_{3} \mathrm{O}_{4}$ catalysts prepared by the impregnation method were investigated for the selective catalytic reduction of $\mathrm{NO}$ by $\mathrm{C}_{3} \mathrm{H}_{6}\left(\mathrm{C}_{3} \mathrm{H}_{6}-\mathrm{SCR}\right)$ in the presence of $\mathrm{O}_{2}$. Their physicochemical properties were analyzed with SEM, XRD, $\mathrm{H}_{2}$-TPR, XPS, PL and IR measurements. It was found that the deposition of $\mathrm{Bi}_{2} \mathrm{O}_{3}$ on $\mathrm{CO}_{3} \mathrm{O}_{4}$ nanoplates enhanced the catalytic activity, especially at low reaction temperature. The $\mathrm{SO}_{2}$ tolerance of $\mathrm{CO}_{3} \mathrm{O}_{4}$ in $\mathrm{C}_{3} \mathrm{H}_{6}$-SCR activity was also improved with the addition of $\mathrm{Bi}_{2} \mathrm{O}_{3}$. Among all catalysts tested, 10.0 wt $\% \mathrm{Bi}_{2} \mathrm{O}_{3} / \mathrm{CO}_{3} \mathrm{O}_{4}$ achieved a $90 \% \mathrm{NO}$ conversion at $200{ }^{\circ} \mathrm{C}$ with the total flow rate

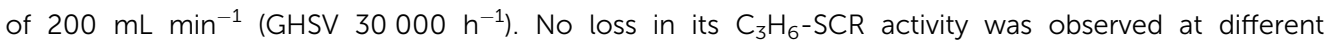
temperatures after the addition of $100 \mathrm{ppm}$ of $\mathrm{SO}_{2}$ to the reaction mixture. These enhanced catalytic behaviors may be associated with the improved oxidizing characteristics of $10.0 \mathrm{wt} \% \mathrm{Bi}_{2} \mathrm{O}_{3} / \mathrm{CO}_{3} \mathrm{O}_{2}$. XRD results showed that $\mathrm{Bi}_{2} \mathrm{O}_{3}$ entered the lattice of $\mathrm{CO}_{3} \mathrm{O}_{4}$, resulting in the formation of lattice distortion and structural defects. $\mathrm{H}_{2}$-TPR results showed that the reduction of $\mathrm{CO}_{3} \mathrm{O}_{4}$ was promoted and the diffusion of oxygen was accelerated with the addition of $\mathrm{Bi}_{2} \mathrm{O}_{3}$. XPS measurements implied that more $\mathrm{Co}^{3+}$ formed on the $10.0 \% \mathrm{Bi}_{2} \mathrm{O}_{3} / \mathrm{CO}_{3} \mathrm{O}_{2}$ catalysts. The improved oxidizing characteristics of the catalyst with the addition of $\mathrm{Bi}_{2} \mathrm{O}_{3}$ due to the synergistic effect of the nanostructure hybrid, thus enhanced the $\mathrm{C}_{3} \mathrm{H}_{6}$ $\mathrm{SCR}$ reaction and hindered the oxidization of $\mathrm{SO}_{2}$. Therefore, the $10.0 \% \mathrm{Bi}_{2} \mathrm{O}_{3} / \mathrm{CO}_{3} \mathrm{O}_{4}$ catalyst exhibited the highest $\mathrm{NO}$ conversion and strongest $\mathrm{SO}_{2}$ tolerance ability.
\end{abstract}

\section{Introduction}

Lean burn engines, which are generally used in gasoline and diesel powered vehicles, are more fuel-efficient than the stoichiometric gasoline engines. ${ }^{1}$ They also effectively reduce unburned hydrocarbons, $\mathrm{CO}_{2}$ and $\mathrm{CO}$ in exhausts. ${ }^{2}$ However, lean burn engines operate with a large excess of air, leading to a significant concentration of oxygen in the exhausts, where the noble-metal three-way catalysts cannot work well to reduce nitrogen oxides $\left(\mathrm{NO}_{x}\right) \cdot{ }^{3}$ A large amount of $\mathrm{NO}_{x}$ produced by lean burn engines leads to serious air pollution and public health problems.

In order to control $\mathrm{NO}_{x}$ emission under the lean burn conditions, selective catalytic reduction of NO by hydrocarbons (e.g. propylene) has been undertaken and reported in the literatures as one potential application (HC-SCR). Many classes of catalysts, including supported noble metals (e.g. $\left.\mathrm{Pt},{ }^{4,5} \mathrm{Au}^{6,7}\right)$, metal oxides (e.g. $\mathrm{Ag}_{2} \mathrm{O},{ }^{\mathbf{8}, 9} \mathrm{CuO},{ }^{10,11} \mathrm{SnO}_{2},{ }^{12-14} \mathrm{CoO}_{x}$ (ref. 15-18)) and zeolite types (ZSM-5, ${ }^{19}$ MCM-41 (ref. 20)) have been investigated. In general, the noble metals are active and stable even at lower temperature, but the formation of $\mathrm{N}_{2} \mathrm{O}$ is undesirable by using

${ }^{a}$ School of Chemistry and Environmental Engineering, Wuhan Institute of Technology, Wuhan 430205, China. E-mail: witchem2018@163.com

${ }^{b}$ School of Chemical Engineering, Hubei University of Arts and Science, Xiangyang 441053, China such precious metals, particularly, platinum-based catalysts. The zeolite-based catalysts were low thermal stability. Among metal oxides catalysts, cobalt oxides (e.g. $\left.\mathrm{Co}_{3} \mathrm{O}_{4}\right)$ are considered as one promising catalyst for HC-SCR due to its high catalytic activity. ${ }^{21}$ When combined with other oxides, such as $\mathrm{CeO}_{2},{ }^{16} \mathrm{ZrO}_{2}{ }^{15}$ $\mathrm{Al}_{2} \mathrm{O}_{3},{ }^{18}$ sulphated $\mathrm{ZrO}_{2},{ }^{22}$ the catalytic performances of the cobalt oxide catalyst could be improved as reported. These results implied that the chemical environment around cobalt oxide plays a crucial role in controlling the overall activity of cobalt containing catalysts in SCR reactions.

$\mathrm{Bi}_{2} \mathrm{O}_{3}$, a common oxide semiconductor, is widely used in the fields of chemical engineering and electronics such as NO detection $^{23}$ and the oxidation or ammoxidation of propylene. ${ }^{24,25}$ In the oxidation/ammoxidation of propene over bismuth/ molybdate catalyst, bismuth was thought to involve the ratedetermining hydrogen abstraction from propylene, ${ }^{26}$ exhibiting its mild oxidizing characteristics. This property might be also beneficial for the partial oxidation of propylene in $\mathrm{C}_{3} \mathrm{H}_{6}$ SCR for NO reduction. Therefore, it is of considerable interest to explore the application of $\mathrm{Bi}_{2} \mathrm{O}_{3}$ in the reduction of $\mathrm{NO}$ with propylene.

In the present study, $\mathrm{Co}_{3} \mathrm{O}_{4}$ nanoplates and $\mathrm{Bi}_{2} \mathrm{O}_{3} / \mathrm{Co}_{3} \mathrm{O}_{4}$ were prepared with the solvothermal and impregnation method respectively. Their catalytic performances in the NO reduction by $\mathrm{C}_{3} \mathrm{H}_{6}$ in the presence of $\mathrm{O}_{2}$ were investigated. The catalysts 
were characterized with X-ray diffraction (XRD), temperature programmed reduction with hydrogen $\left(\mathrm{H}_{2}-\mathrm{TPR}\right)$, and X-ray photoelectron spectra (XPS). The effects of $\mathrm{Bi}_{2} \mathrm{O}_{3}$ on the selective catalytic reduction of $\mathrm{NO}$ by propylene over $\mathrm{Co}_{3} \mathrm{O}_{4}$ nanoplates were expected to be elucidated.

\section{Experimental}

\subsection{Preparation of $\mathrm{Co}_{3} \mathrm{O}_{4}$ and $\mathrm{Bi}_{2} \mathrm{O}_{3} / \mathrm{Co}_{3} \mathrm{O}_{4}$}

The $\mathrm{Co}_{3} \mathrm{O}_{4}$ support was synthesized via the solvent-thermal method, $50 \mathrm{mmol} \mathrm{CoCl}_{2}$ solution $\left(200 \mathrm{mmol} \mathrm{L}^{-1}\right.$, Sinopharm Chemical Reagent Co. China) and $25 \mathrm{~mL}$ of $\mathrm{NaOH}\left(2 \mathrm{~mol} \mathrm{~L}^{-1}\right.$, Sinopharm Chemical Reagent Co. China) were added to a roundbottom flask, ultrasonicated for about 20 minutes to obtain a light brown uniform suspension. And then the suspension was transferred into a stainless steel autoclave with Teflon liner. The autoclave was sealed and maintained at $120^{\circ} \mathrm{C}$ for $12 \mathrm{~h}$. The obtained product was collected after washing with deionized water for several times, finally calcined at $500{ }^{\circ} \mathrm{C}$ for $5 \mathrm{~h}$ in air (S1).

The $\mathrm{Bi}_{2} \mathrm{O}_{3} / \mathrm{Co}_{3} \mathrm{O}_{4}$ catalysts with different $\mathrm{Bi}_{2} \mathrm{O}_{3}$ contents were synthesized by impregnation method as followed: $0.0155 \mathrm{~g}$ $\mathrm{Bi}\left(\mathrm{NO}_{3}\right)_{3} \cdot 5 \mathrm{H}_{2} \mathrm{O}$ and $20 \mathrm{~mL} 3 \% \mathrm{NH}_{3} \cdot \mathrm{H}_{2} \mathrm{O}$ were added into a round-bottom flask, ultrasonicated for about 20 minutes to obtain a white uniform suspension. After that, the $\mathrm{Co}_{3} \mathrm{O}_{4}$ support (S1) were added in the suspension, ultrasonicated for about 15 minutes to make it homogeneously distributed in the suspension. The suspension was then dried at $80{ }^{\circ} \mathrm{C}$ with continuous stirring for $1 \mathrm{~h}$, further heated at $120^{\circ} \mathrm{C}$ for $12 \mathrm{~h}$ followed by calcination at $500{ }^{\circ} \mathrm{C}$ in air for $4 \mathrm{~h}$, yielding the $5.0 \mathrm{wt} \% \mathrm{Bi}_{2} \mathrm{O}_{3} / \mathrm{Co}_{3} \mathrm{O}_{4}$ catalyst (S2). $10.0 \mathrm{wt} \% \mathrm{Bi}_{2} \mathrm{O}_{3} / \mathrm{Co}_{3} \mathrm{O}_{4}$ (S3) and $15.0 \mathrm{wt} \% \mathrm{Bi}_{2} \mathrm{O}_{3} / \mathrm{Co}_{3} \mathrm{O}_{4}(\mathrm{~S} 4)$ were prepared with $0.0310 \mathrm{~g}$ and $0.0465 \mathrm{~g} \mathrm{Bi}\left(\mathrm{NO}_{3}\right)_{3} \cdot 5 \mathrm{H}_{2} \mathrm{O}$ respectively. In addition, the physical mixture of $10 \% \mathrm{Bi}_{2} \mathrm{O}_{3}$ nanoparticles and $\mathrm{Co}_{3} \mathrm{O}_{4}$ support was also prepared and labeled as S5. As references, classical catalysts $4 \%$ $\mathrm{Ag} / \mathrm{Al}_{2} \mathrm{O}_{3}$ and $2 \% \mathrm{Pt} / \mathrm{Al}_{2} \mathrm{O}_{3}$ were prepared to compare the catalytic performance of the $\mathrm{Bi}_{2} \mathrm{O}_{3} / \mathrm{Co}_{3} \mathrm{O}_{4}$ catalysts.

\subsection{Catalytic activity tests}

$\mathrm{C}_{3} \mathrm{H}_{6}$-SCR over the catalysts was carried out at atmospheric pressure in a fixed-bed quartz reactor (diameter $=10 \mathrm{~mm}$ ). $0.1 \mathrm{~g}$ catalyst was used in each run with a reaction mixture composed of $200 \mathrm{ppm} \mathrm{NO}, 200 \mathrm{ppm} \mathrm{C}_{3} \mathrm{H}_{6}, 100 \mathrm{ppm} \mathrm{SO}_{2}$ (when needed) and 10 vol\% $\mathrm{O}_{2}$ in balance gas $\mathrm{N}_{2}$. The total flow rate was 200 $\mathrm{mL} \min ^{-1}$, corresponding to a GHSV $30000 \mathrm{~h}^{-1}$. Reaction temperature ranges from 100 to $500{ }^{\circ} \mathrm{C}$. The concentration of NO was continuously measured by a NO analyzer (Thermo Environmental Instruments Inc., model 42c), which monitors $\mathrm{NO}, \mathrm{NO}_{2}$, and $\mathrm{NO}_{x}\left(\mathrm{NO}_{x}\right.$ represents $\left.\mathrm{NO}+\mathrm{NO}_{2}\right)$. The removal efficiency of $\mathrm{NO}$ was calculated as NO removal $(\%)=\left(1-C / C_{0}\right)$ $\times 100 \%$, where $C$ and $C_{0}$ are concentrations of NO in the outlet and inlet, respectively.

\subsection{Catalysts characterization}

Scanning electron microscopy (SEM) images were taken on a Hitachi 54800 scanning electron microscope operating at 5.0 $\mathrm{kV}$. X-ray powder diffraction (XRD) was carried out on
Brukeraxs D8 Discover $(\mathrm{Cu} \mathrm{K} \alpha=1.5406 \AA$ ̊). The scanning rate is $1^{\circ} \mathrm{min}^{-1}$ in the $2 \theta$ range from 20 to 80 degree. The reducibility of $\mathrm{Bi}_{2} \mathrm{O}_{3} / \mathrm{Co}_{3} \mathrm{O}_{4}$ catalysts was estimated by temperature programmed reduction with hydrogen analysis $\left(\mathrm{H}_{2}-\mathrm{TPR}\right)$. The experiments were carried out with a Micromeritics 2910 apparatus using $\mathrm{H}_{2} / \mathrm{Ar}(3 / 97, \mathrm{v} / \mathrm{v})$ gas with a total flow rate of 15 $\mathrm{mL} \mathrm{min}^{-1}$. In each run, $0.030 \mathrm{~g}$ of the catalyst was previously activated at $500{ }^{\circ} \mathrm{C}$ for $30 \mathrm{~min}$ under air, and then cooled to RT. TPR started with the introduction of the mixture of $\mathrm{H}_{2}$ and Ar. The catalyst was heated from room temperature (RT) to $1000{ }^{\circ} \mathrm{C}\left(10{ }^{\circ} \mathrm{C} \mathrm{min}^{-1}\right) . \mathrm{H}_{2}$ consumption was continuously monitored with the thermal conductivity detector. X-ray photoelectron spectra (XPS) of the catalysts were measured in a VG Multilab 2000 spectrometer by using $\mathrm{Al} \mathrm{K} \alpha(1486.6 \mathrm{eV})$ radiation as the X-ray source. Photoluminescence (PL) measurement was carried out on a Shimadzu RF-5301 PC fluorescence spectrophotometer. Raman spectra were recorded using a Horiba Jobin-Yvon Lab Ram HR800 Raman microspectrometer, with an excitation laser at $514 \mathrm{~nm}$.

\section{Results}

\subsection{Scanning electron microscope (SEM) observation and XRD analysis}

$\mathrm{Co}_{3} \mathrm{O}_{4}$ nanoplates with different dimensions were observed on the support $\mathrm{Co}_{3} \mathrm{O}_{4}(\mathrm{~S} 1)$, shown in Fig. 1(a). Fig. 1(b-d) presented $\mathrm{Bi}_{2} \mathrm{O}_{3} / \mathrm{Co}_{3} \mathrm{O}_{4}$ catalysts with different $\mathrm{Bi}_{2} \mathrm{O}_{3}$ loading amounts. It was shown that $\mathrm{Bi}_{2} \mathrm{O}_{3}$ nanoparticles with dimension $c a .20 \mathrm{~nm}$ were supported on $\mathrm{Co}_{3} \mathrm{O}_{4}$. And the crystal size of $\mathrm{Bi}_{2} \mathrm{O}_{3}$ slightly increased with increasing $\mathrm{Bi}_{2} \mathrm{O}_{3}$ loading amount from $5 \%$ to $15 \%$.

Fig. 2(A) shows the XRD patterns of the synthesized $\mathrm{Co}_{3} \mathrm{O}_{4}$ and $\mathrm{Bi}_{2} \mathrm{O}_{3} / \mathrm{Co}_{3} \mathrm{O}_{4}$ catalysts. It can be seen that the $\mathrm{Co}_{3} \mathrm{O}_{4}$ support possessed the characteristic peaks of $\mathrm{Co}_{3} \mathrm{O}_{4}$ (JCPDS 73-1701, $a=$ $5.45 \AA$ ). Besides the characteristic peaks of $\mathrm{Co}_{3} \mathrm{O}_{4}$, the diffraction peaks due to $\mathrm{Bi}_{2} \mathrm{O}_{3}$ (JCPDS 22-515, $a=10.94 \AA$ and $c=11.28$ $\AA$ ) were also observed on $\mathrm{Bi}_{2} \mathrm{O}_{3} / \mathrm{Co}_{3} \mathrm{O}_{4}$ catalysts which became sharper with the increase of $\mathrm{Bi}_{2} \mathrm{O}_{3}$ loading amount. It was suggested that the crystal size of $\mathrm{Bi}_{2} \mathrm{O}_{3}$ was bigger on the catalyst with higher loading amount of $\mathrm{Bi}_{2} \mathrm{O}_{3}$, which was consistent with the SEM observations. Moreover, the diffraction peaks of $\mathrm{Co}_{3} \mathrm{O}_{4}$ over $\mathrm{Bi}_{2} \mathrm{O}_{3} / \mathrm{Co}_{3} \mathrm{O}_{4}$ catalysts behaved a slight shift towards lower degree in comparison with that of $\mathrm{Co}_{3} \mathrm{O}_{4}$, shown in Fig. 2(B). It indicated that the $\mathrm{Bi}^{3+}$ inserted the lattice of $\mathrm{Co}_{3} \mathrm{O}_{4}$ in the preparation process, and changed the lattice parameter of $\mathrm{Co}_{3} \mathrm{O}_{4}$ due to the different radius of $\mathrm{Bi}$ and $\mathrm{Co}$ atoms. At the same time, the characteristic peak of $\mathrm{Co}_{3} \mathrm{O}_{4}$ became weak obviously after the deposition of $\mathrm{Bi}_{2} \mathrm{O}_{3}$, which revealed the reduction of crystal size. It was implied that the insertion of $\mathrm{Bi}_{2} \mathrm{O}_{3}$ induced the structure defect of $\mathrm{Co}_{3} \mathrm{O}_{4}$ and suppressed the growth of crystal.

\subsection{Temperature-programmed reduction by hydrogen $\left(\mathrm{H}_{2}\right.$ - TPR)}

The $\mathrm{H}_{2}$-TPR profiles of $\mathrm{Co}_{3} \mathrm{O}_{4}, \mathrm{Bi}_{2} \mathrm{O}_{3}$ and $\mathrm{Bi}_{2} \mathrm{O}_{3} / \mathrm{Co}_{3} \mathrm{O}_{4}$ catalysts were shown in Fig. 3. For the reduction of $\mathrm{Bi}_{2} \mathrm{O}_{3}$, a sharp peak 

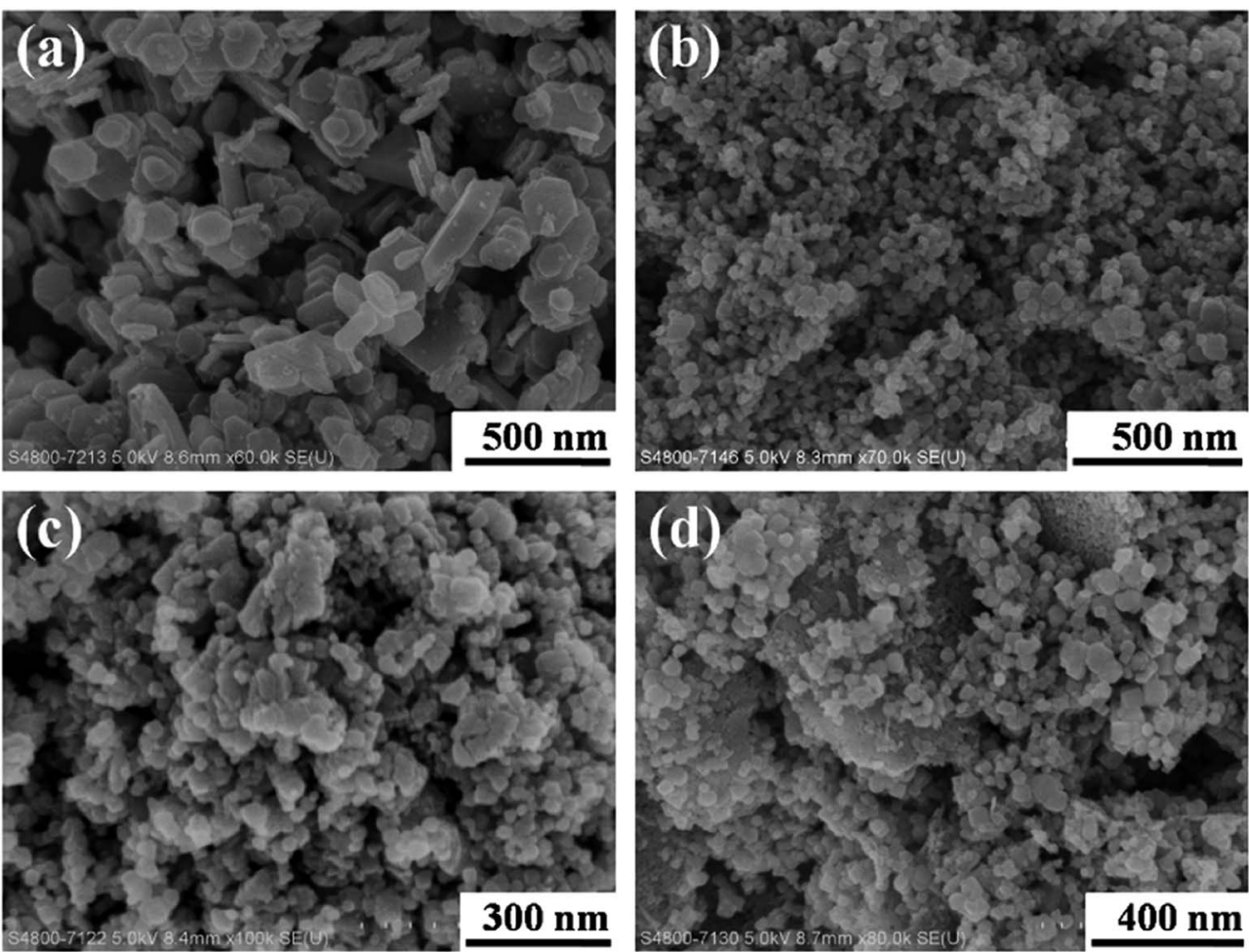

Fig. $1 \mathrm{SEM}$ images of $\mathrm{CO}_{3} \mathrm{O}_{4}$ (a), $5.0 \% \mathrm{Bi}_{2} \mathrm{O}_{3} / \mathrm{Co}_{3} \mathrm{O}_{4}$ (b), $10.0 \% \mathrm{Bi}_{2} \mathrm{O}_{3} / \mathrm{Co}_{3} \mathrm{O}_{4}$ (c) and $15.0 \% \mathrm{Bi}_{2} \mathrm{O}_{3} / \mathrm{Co}_{3} \mathrm{O}_{4}$ (d).

was observed at $c a .490{ }^{\circ} \mathrm{C}$, implying the reduction of $\mathrm{Bi}^{3+}$ in a narrow temperature range. A broad reduction peak from 330 to $460{ }^{\circ} \mathrm{C}$ with a large shoulder at the lower reduction temperature ( $\mathrm{ca} .380{ }^{\circ} \mathrm{C}$ ) appeared on $\mathrm{Co}_{3} \mathrm{O}_{4}$ support (S1). Many researchers reported that the reduction of $\mathrm{Co}_{3} \mathrm{O}_{4}$ was a two-step reduction process involving the intermediate reduction of CoO. ${ }^{16,21,27}$ Two main clear reduction peaks respectively located around $186{ }^{\circ} \mathrm{C}$ and $310-480{ }^{\circ} \mathrm{C}$ were shown in the TPR spectra. The low temperature TPR peak was associated with the reduction of $\mathrm{Co}^{3+}$ to $\mathrm{Co}^{2+}$, and the peak at high temperature was the subsequent reduction of $\mathrm{CoO}$ to metallic cobalt. In the TPR spectrum of $\mathrm{Co}_{3} \mathrm{O}_{4}$ synthesized in the present work, there are no obvious two peaks probably due to an abroad particle size distribution as shown in SEM observation. The large shoulder at $376^{\circ} \mathrm{C}$ (peak I) in Fig. 3 should be attributed to the reduction of $\mathrm{Co}^{3+}$ to $\mathrm{Co}^{2+}$, and main reduction peak (peak II) is ascribed to the reduction of $\mathrm{CoO}$ to metallic cobalt.

The reduction process of $\mathrm{Bi}_{2} \mathrm{O}_{3} / \mathrm{Co}_{3} \mathrm{O}_{4}$ catalysts (S2-S4) became complicated with the introduction of $\mathrm{Bi}_{2} \mathrm{O}_{3}$. The reduction peak at $487{ }^{\circ} \mathrm{C}$ became wider and shifted towards to the lower temperature, especially on the $\mathrm{Bi}_{2} \mathrm{O}_{3} / \mathrm{Co}_{3} \mathrm{O}_{4}$ catalyst with the highest $\mathrm{Bi}$ loading amount (S4). In addition, two new peaks around $342{ }^{\circ} \mathrm{C}$ (peak I) and $402{ }^{\circ} \mathrm{C}$ (peak II) respectively ascribed to the reduction of $\mathrm{Co}^{3+}$ to $\mathrm{Co}^{2+}, \mathrm{Co}^{2+}$ to metallic $\mathrm{Co}$ appeared on $\mathrm{Bi}_{2} \mathrm{O}_{3} / \mathrm{Co}_{3} \mathrm{O}_{4}$ catalysts ( $\left.\mathrm{S} 2-\mathrm{S} 4\right) .{ }^{28}$ Compared with the bulk $\mathrm{Co}_{3} \mathrm{O}_{4}(\mathrm{~S} 1)$, both the reduction peak of $\mathrm{Co}^{3+}$ and that of $\mathrm{Co}^{2+}$ shifted to lower temperature after the deposition of $\mathrm{Bi}_{2} \mathrm{O}_{3}$, implying the promoted reduction of $\mathrm{Co}_{3} \mathrm{O}_{4}$. Moreover, the larger reduction peak I than peak II on S2-S4 samples indicated that the ratio of $\mathrm{Co}^{3+} / \mathrm{Co}^{2+}$ was higher on S2-S4 samples than that on the $\mathrm{Co}_{3} \mathrm{O}_{4}(\mathrm{~S} 1)$. It revealed that the deposition of $\mathrm{Bi}_{2} \mathrm{O}_{3}$ on $\mathrm{Co}_{3} \mathrm{O}_{4}$ affected the oxidized state of cobalt in the synthesized $\mathrm{Co}_{3} \mathrm{O}_{4}$, more $\mathrm{Co}^{3+}$ were present on the supported samples (S2-S4) than the pure $\mathrm{Co}_{3} \mathrm{O}_{4}$.

\subsection{X-ray photoelectron spectroscopy (XPS)}

XPS measurements were carried out on $\mathrm{Co}_{3} \mathrm{O}_{4}$ and $10.0 \% \mathrm{Bi}_{2} \mathrm{O}_{3} /$ $\mathrm{Co}_{3} \mathrm{O}_{4}$ catalysts to examine the influence of $\mathrm{Bi}_{2} \mathrm{O}_{3}$ on the surface electronic state of $\mathrm{Co}_{3} \mathrm{O}_{4}$. The Co 2p and O 1s XPS profiles are shown in Fig. 4. In the Co 2p (Fig. 7(a)), the main peaks located at $779.6-781.3 \mathrm{eV}$ and $794.8-796.5 \mathrm{eV}$ are ascribed to Co $2 \mathrm{p}_{1 / 2}$ and Co $2 \mathrm{p}_{3 / 2}$ spin-orbital peaks, respectively. ${ }^{29,30}$ It was wellknown that the spin-orbit splitting value for $\mathrm{Co}^{3+}$ compounds is $15.0 \mathrm{eV}, 15.1-15.3 \mathrm{eV}$ for the mixed-valence $\mathrm{Co}_{3} \mathrm{O}_{4}$. Here, the spin-orbit splitting values of Co $2 \mathrm{p}$ for $\mathrm{CO}_{3} \mathrm{O}_{4}$ and $10.0 \% \mathrm{Bi}_{2} \mathrm{O}_{3} /$ $\mathrm{Co}_{3} \mathrm{O}_{4}$ are the same, $15.2 \mathrm{eV}$, which is close to that of mixedvalence $\mathrm{Co}_{3} \mathrm{O}_{4}$. So the cobalt species on both $\mathrm{S} 1$ and $\mathrm{S} 3$ should be $\mathrm{Co}_{3} \mathrm{O}_{4}$, agreeable with the XRD and TPR results.

Based on the restriction that Co $2 \mathrm{p}_{3 / 2}$ binding energies of $\mathrm{Co}^{2+}$ and $\mathrm{Co}^{3+}$ components are $781.3 \mathrm{eV}$ and $779.6 \mathrm{eV}$, respectively, the spin-orbit doublet splitting is $15.2 \mathrm{eV}$ with a fixed ratio of $2 / 1$ for the $2 \mathrm{p}_{3 / 2}$-to- $2 \mathrm{p}_{1 / 2}$ peak area, ${ }^{29}$ the Co $2 \mathrm{p}$ spectra of $\mathrm{S} 1$ and $\mathrm{S} 3$ can be fitted to the $\mathrm{Co}^{2+}$ (peak II and IV) and $\mathrm{Co}^{3+}$ (peak I and III) components. ${ }^{30,31}$ The satellite peak of $\mathrm{Co}^{2+}$ and that of $\mathrm{Co}^{3+}$ in $\mathrm{Co}_{3} \mathrm{O}_{4}$ were also respectively observed at $787.0 \mathrm{eV}$ and $791.0 \mathrm{eV}^{.32,33}$ Fig. 4 shows that the peak areas of peak I and III increased with the addition of $\mathrm{Bi}_{2} \mathrm{O}_{3}$, implying that the surface $\mathrm{Co}^{3+}$ and the surface content ratio of $\mathrm{Co}^{3+} / \mathrm{Co}^{2+}$ 

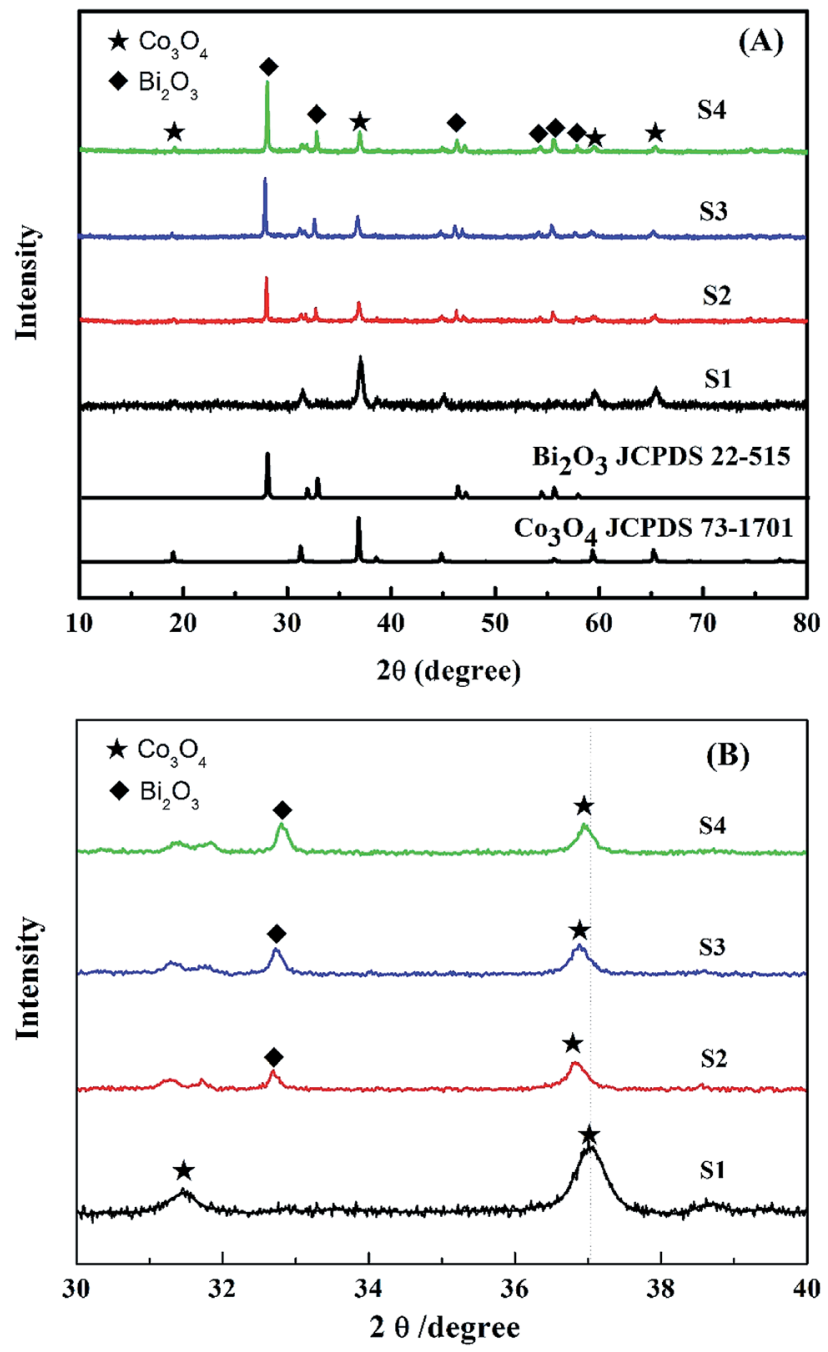

Fig. 2 XRD patterns of $\mathrm{CO}_{3} \mathrm{O}_{4}$ (S1), $5.0 \% \mathrm{Bi}_{2} \mathrm{O}_{3} / \mathrm{CO}_{3} \mathrm{O}_{4}$ (S2), $10.0 \%$ $\mathrm{Bi}_{2} \mathrm{O}_{3} / \mathrm{CO}_{3} \mathrm{O}_{4}$ (S3) and $15.0 \% \mathrm{Bi}_{2} \mathrm{O}_{3} / \mathrm{CO}_{3} \mathrm{O}_{4}$ (S4) in the wide (A) and narrow (B) ranges.

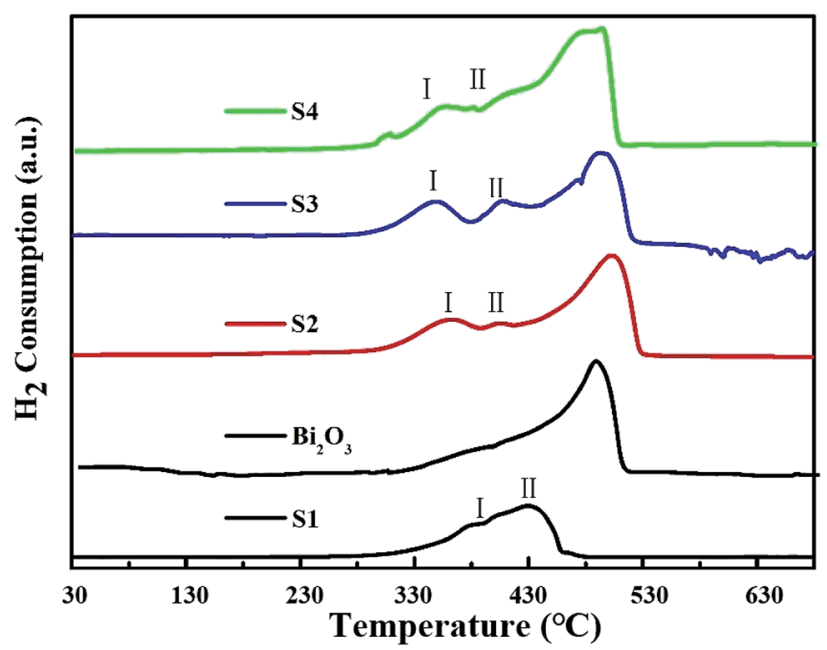

Fig. $3 \mathrm{H}_{2}$-TPR profiles of pure $\mathrm{CO}_{3} \mathrm{O}_{4}(\mathrm{~S} 1), \mathrm{Bi}_{2} \mathrm{O}_{3}, 5.0 \% \mathrm{Bi}_{2} \mathrm{O}_{3} / \mathrm{CO}_{3} \mathrm{O}_{4}$ (S2), $10.0 \% \mathrm{Bi}_{2} \mathrm{O}_{3} / \mathrm{CO}_{3} \mathrm{O}_{4}$ (S3) and $15.0 \% \mathrm{Bi}_{2} \mathrm{O}_{3} / \mathrm{CO}_{3} \mathrm{O}_{4}$ (S4). increased with the addition of $\mathrm{Bi}_{2} \mathrm{O}_{3}$. More $\mathrm{Co}^{3+}$ was present on $10.0 \% \mathrm{Bi}_{2} \mathrm{O}_{3} / \mathrm{Co}_{3} \mathrm{O}_{4}$ (S3) than the bulk $\mathrm{Co}_{3} \mathrm{O}_{4}$ support (S1), as consistent with the TPR results.

The $\mathrm{O}$ 1s XPS spectra of $\mathrm{Co}_{3} \mathrm{O}_{4}$ and $\mathrm{Bi}_{2} \mathrm{O}_{3} / \mathrm{Co}_{3} \mathrm{O}_{4}$ catalysts are shown in Fig. 4(b). For the $\mathrm{Co}_{3} \mathrm{O}_{4}$ sample, there are two peaks (I and II). The peak I located at $\sim 530.1 \mathrm{eV}$ is attributed to the surface lattice of $\mathrm{Co}_{3} \mathrm{O}_{4}$, and the peak II at $\sim 531.5 \mathrm{eV}$ is associated with $\mathrm{OH}^{-}$groups. ${ }^{34}$ In the case of $10.0 \% \mathrm{Bi}_{2} \mathrm{O}_{3} / \mathrm{Co}_{3} \mathrm{O}_{4}$, besides the peak I and II, one new peak at $\sim 532.8 \mathrm{eV}$ appeared, which should be related to the contribution of the oxygen from $\mathrm{Bi}_{2} \mathrm{O}_{3}$.

\subsection{Photoluminescence (PL) and Raman spectra}

PL emission spectra originating from the recombination of free charge carriers are useful to reveal the migration, transfer and separation of photogenerated charge carriers. Fig. 5 shows photoluminescence emission spectra of different catalysts at room temperature. All samples show one luminescence peak center at about $358 \mathrm{~nm}$, which can be attributed to the radiative recombination of charge carriers. The pure $\mathrm{Co}_{3} \mathrm{O}_{4}$ has the strongest $\mathrm{PL}$ emission peak. This charge recombination process of $\mathrm{Co}_{3} \mathrm{O}_{4}$ can be greatly inhibited by the deposition of $\mathrm{Bi}_{2} \mathrm{O}_{3}$ on
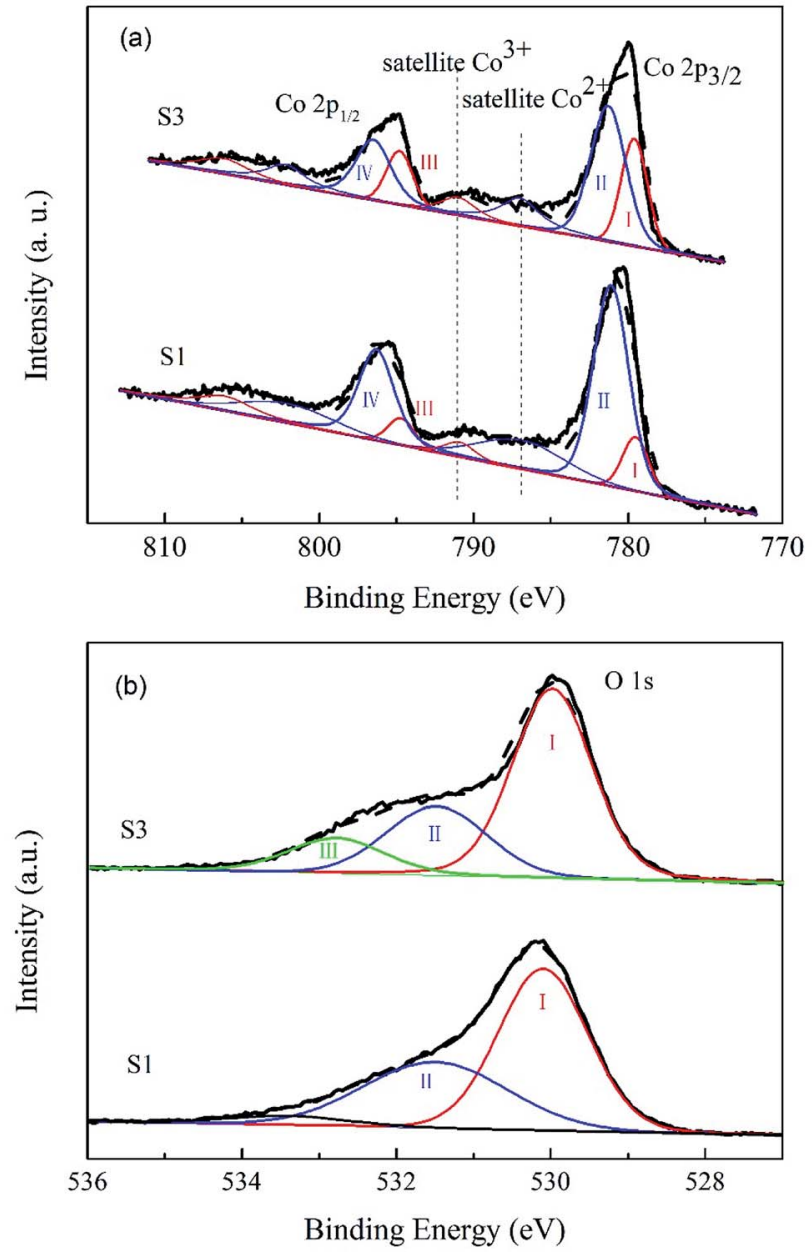

Fig. 4 XPS study of $\mathrm{CO}_{3} \mathrm{O}_{4}$ (S1) and $10.0 \% \mathrm{Bi}_{2} \mathrm{O}_{3} / \mathrm{CO}_{3} \mathrm{O}_{4}$ (S3): (a) $\mathrm{Co} 2 \mathrm{p}$ spectra, (b) $\bigcirc 1$ s spectra. 


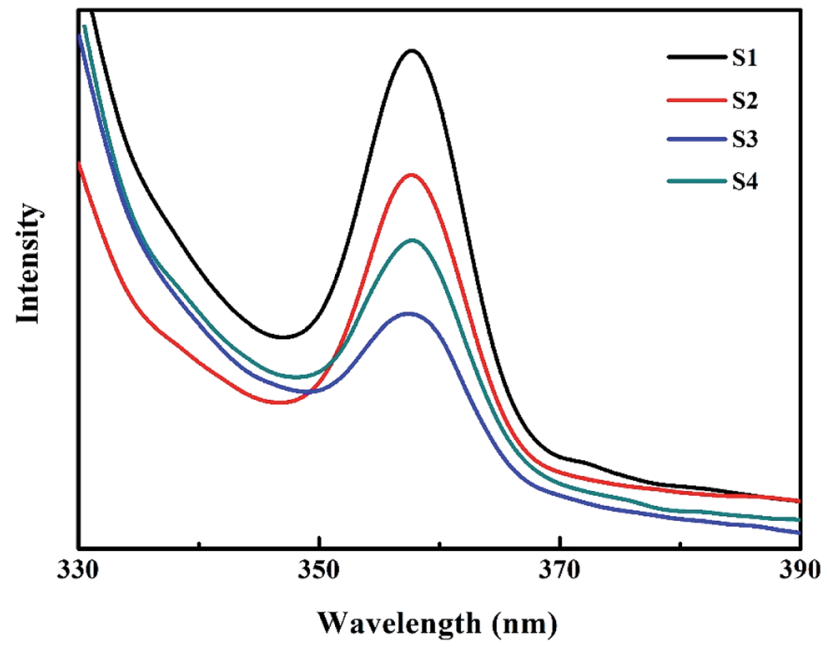

Fig. 5 Room-temperature $\mathrm{PL}$ spectra of $\mathrm{CO}_{3} \mathrm{O}_{4}$ (S1), $5.0 \% \mathrm{Bi}_{2} \mathrm{O}_{3} /$ $\mathrm{CO}_{3} \mathrm{O}_{4}$ (S2), $10.0 \% \mathrm{Bi}_{2} \mathrm{O}_{3} / \mathrm{CO}_{3} \mathrm{O}_{4}$ (S3) and $15.0 \% \mathrm{Bi}_{2} \mathrm{O}_{3} / \mathrm{CO}_{3} \mathrm{O}_{4}$ (S4).

$\mathrm{Co}_{3} \mathrm{O}_{4} \cdot 10.0 \% \mathrm{Bi}_{2} \mathrm{O}_{3} / \mathrm{Co}_{3} \mathrm{O}_{4}(\mathrm{~S} 3)$ has the lowest PL emission peak, which is associated with its structural imperfection. The structural imperfection originating from the insertion of the $\mathrm{Bi}^{3+}$ into the lattice of $\mathrm{Co}_{3} \mathrm{O}_{4}$, as evidenced by $\mathrm{XRD}$, increased the number of structural defects (e.g., oxygen vacancies), which could capture the electrons or holes, thus resulting in low radiative PL emission.

Fig. 6 shows the Raman spectra of $10.0 \% \mathrm{Bi}_{2} \mathrm{O}_{3} / \mathrm{Co}_{3} \mathrm{O}_{4}$ (S3), pure $\mathrm{Co}_{3} \mathrm{O}_{4}(\mathrm{~S} 1)$ and $\mathrm{Bi}_{2} \mathrm{O}_{3}$. For the pure $\mathrm{Co}_{3} \mathrm{O}_{4}$, the Raman peak at $655 \mathrm{~cm}^{-1}$ was corresponded to the symmetry of $\mathrm{Co}_{3} \mathrm{O}_{4} \cdot{ }^{35}$ $10.0 \% \mathrm{Bi}_{2} \mathrm{O}_{3} / \mathrm{Co}_{3} \mathrm{O}_{4}$ gave the similar Raman spectra with $\mathrm{Co}_{3} \mathrm{O}_{4}$, while the characteristic peaks of $\mathrm{Bi}_{2} \mathrm{O}_{3}$ could not be detected. Compared with $\mathrm{Co}_{3} \mathrm{O}_{4}$, the Raman peaks on $10.0 \% \mathrm{Bi}_{2} \mathrm{O}_{3} / \mathrm{Co}_{3} \mathrm{O}_{4}$ shifted to the lower frequencies with stronger intensities, which associated with the lattice distortion or residual stress of the spinel structure. The XRD results showed that part of $\mathrm{Bi}_{2} \mathrm{O}_{3}$ entered the lattice of $\mathrm{Co}_{3} \mathrm{O}_{4}$ over $10.0 \% \mathrm{Bi}_{2} \mathrm{O}_{3} / \mathrm{Co}_{3} \mathrm{O}_{4}$, leading to

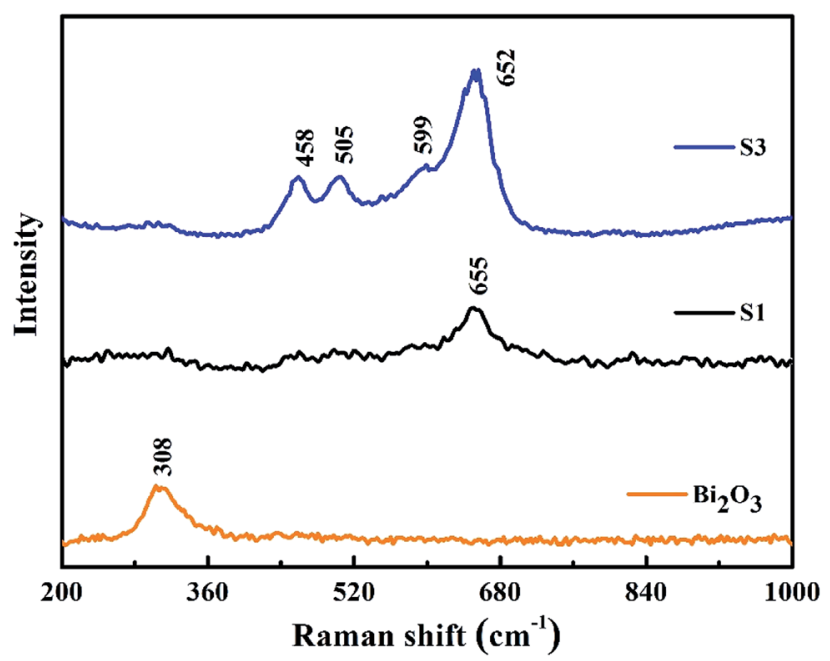

Fig. 6 Raman spectra of $\mathrm{CO}_{3} \mathrm{O}_{4}(\mathrm{~S} 1)$ and $10.0 \% \mathrm{Bi}_{2} \mathrm{O}_{3} / \mathrm{CO}_{3} \mathrm{O}_{4}(\mathrm{~S} 3)$.

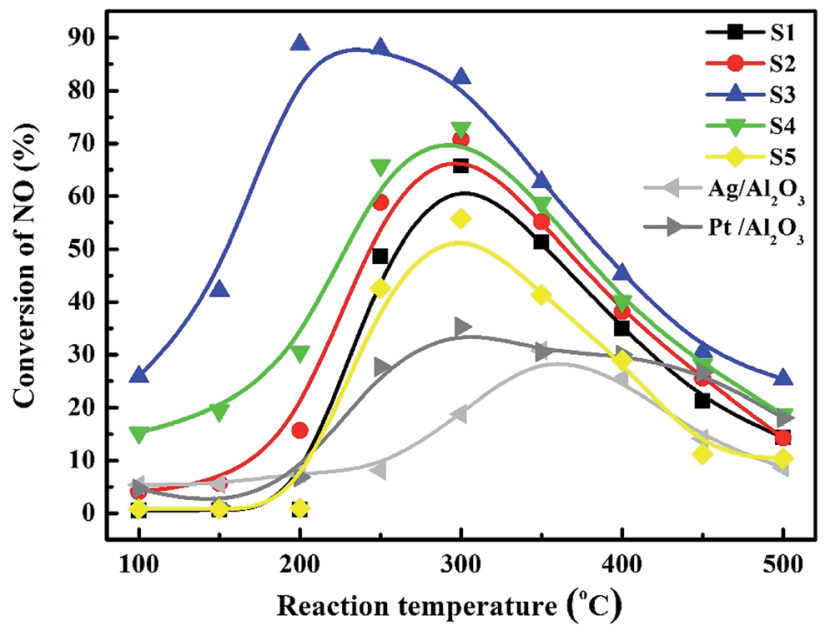

Fig. $7 \mathrm{NO}$ conversions over the catalysts: $\mathrm{S} 1: \mathrm{CO}_{3} \mathrm{O}_{4} ; \mathrm{S} 2: 5.0 \% \mathrm{Bi}_{2} \mathrm{O}_{3} /$ $\mathrm{CO}_{3} \mathrm{O}_{4} ; \mathrm{S3}: 10.0 \% \quad \mathrm{Bi}_{2} \mathrm{O}_{3} / \mathrm{CO}_{3} \mathrm{O}_{4} ; \mathrm{S} 4: 15.0 \% \quad \mathrm{Bi}_{2} \mathrm{O}_{3} / \mathrm{CO}_{3} \mathrm{O}_{4} ;$ S5: the physical mixture of $\mathrm{Bi}_{2} \mathrm{O}_{3}$ and $\mathrm{CO}_{3} \mathrm{O}_{4}$.

the lattice distortion and lattice defect. The highly defective structure formed on $10.0 \% \mathrm{Bi}_{2} \mathrm{O}_{3} / \mathrm{Co}_{3} \mathrm{O}_{4}$ could accelerate the adsorption and activation of $\mathrm{O}_{2}$, which was suggested to be related to the better catalytic performance.

\subsection{Catalytic performance}

Fig. 7 depicted the NO conversions over the $\mathrm{Bi}_{2} \mathrm{O}_{3} / \mathrm{Co}_{3} \mathrm{O}_{4}$ catalysts with different $\mathrm{Bi}_{2} \mathrm{O}_{3}$ contents (S1-S4), the physical mixture of $10 \% \mathrm{Bi}_{2} \mathrm{O}_{3}$ nanoparticles and $\mathrm{Co}_{3} \mathrm{O}_{4}$ support (S5), $4 \% \mathrm{Ag} /$ $\mathrm{Al}_{2} \mathrm{O}_{3}$ and $2 \% \mathrm{Pt} / \mathrm{Al}_{2} \mathrm{O}_{3}$ reference catalysts within the reaction temperature range of $100-500{ }^{\circ} \mathrm{C} . \mathrm{Co}_{3} \mathrm{O}_{4}$ and $\mathrm{Bi}_{2} \mathrm{O}_{3} / \mathrm{Co}_{3} \mathrm{O}_{4}$ catalysts showed higher NO reduction activity than those of $\mathrm{Ag} /$ $\mathrm{Al}_{2} \mathrm{O}_{3}$ and $\mathrm{Pt} / \mathrm{Al}_{2} \mathrm{O}_{3}$, especially $\mathrm{Bi}_{2} \mathrm{O}_{3} / \mathrm{Co}_{3} \mathrm{O}_{4}$ catalysts. The conversion of $\mathrm{NO}$ over $\mathrm{Co}_{3} \mathrm{O}_{4}$ support (S1) firstly increased with reaction temperature, reached the maximum conversion ( $c a$. $60 \%$ ) at $c a .300{ }^{\circ} \mathrm{C}$ and then decreased at higher temperature. The NO conversion was further increased with the addition of $\mathrm{Bi}_{2} \mathrm{O}_{3}$ into $\mathrm{Co}_{3} \mathrm{O}_{4}$ with the activity order: $\mathrm{Co}_{3} \mathrm{O}_{4}(\mathrm{~S} 1)<5.0 \%$ $\mathrm{Bi}_{2} \mathrm{O}_{3} / \mathrm{Co}_{3} \mathrm{O}_{4}(\mathrm{~S} 2)<15.0 \% \mathrm{Bi}_{2} \mathrm{O}_{3} / \mathrm{Co}_{3} \mathrm{O}_{4}(\mathrm{~S} 4)<10.0 \% \mathrm{Bi}_{2} \mathrm{O}_{3} / \mathrm{Co}_{3} \mathrm{O}_{4}$ (S3). Among all catalysts tested, $10.0 \% \mathrm{Bi}_{2} \mathrm{O}_{3} / \mathrm{Co}_{3} \mathrm{O}_{4}$ (S3) possessed the highest activity for $\mathrm{NO}$ conversion in the reaction temperature window, reaching $c a .90 \%$ NO conversion at $200{ }^{\circ} \mathrm{C}$. NO conversion under the lower reaction temperature $\left(100-250^{\circ} \mathrm{C}\right)$ over $\mathrm{S} 3$ also reached the highest among the catalysts tested. In contrast, the mixture of $10 \% \mathrm{Bi}_{2} \mathrm{O}_{3}$ nanoparticles and $\mathrm{Co}_{3} \mathrm{O}_{4}$ support ( $\mathrm{S} 5$ ) showed lower activity than $\mathrm{S} 1$ and $\mathrm{S} 3$. It was indicated that the interaction between $\mathrm{Bi}_{2} \mathrm{O}_{3}$ and $\mathrm{Co}_{3} \mathrm{O}_{4}$ in $\mathrm{S} 3$ is not the simply physical mixture like $\mathrm{S} 5$. The chemical interaction between them took place in S3 and should contribute the admirable catalytic performance of $\mathrm{S} 3$ in the $\mathrm{C}_{3} \mathrm{H}_{6}$-SCR reaction.

$\mathrm{SO}_{2}$ usually exists in the diesel engine exhaust. So it is necessary to investigate the $\mathrm{SO}_{2}$ tolerance of the catalyst in $\mathrm{C}_{3} \mathrm{H}_{6}$-SCR. Fig. 8 exhibited the effects of $100 \mathrm{ppm} \mathrm{SO}_{2}$ co-fed in the reaction gas on the NO conversions over the catalysts at the different reaction temperatures. NO conversion over the S3 


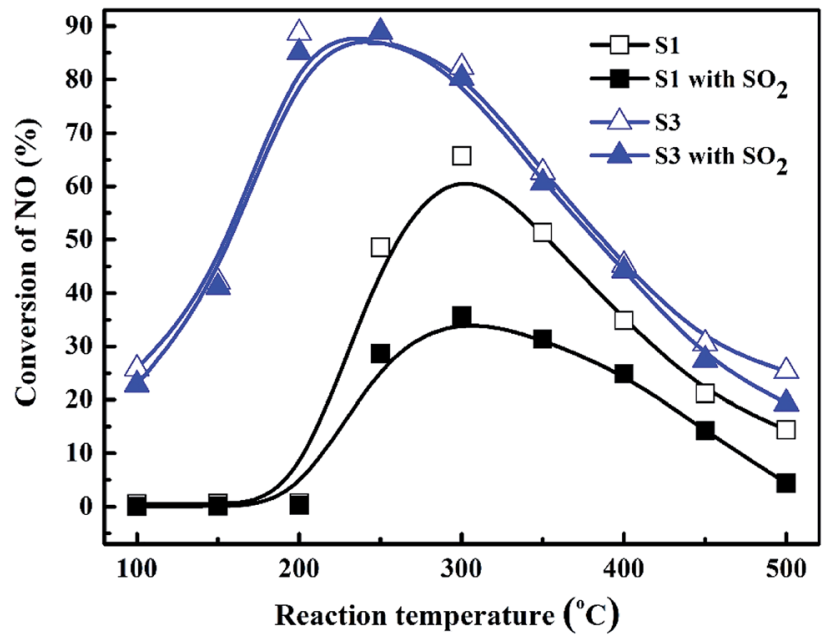

Fig. $8 \mathrm{SO}_{2}$ resistibilities of $\mathrm{CO}_{3} \mathrm{O}_{4}(\mathrm{~S} 1)$ and $10.0 \% \mathrm{Bi}_{2} \mathrm{O}_{3} / \mathrm{CO}_{3} \mathrm{O}_{4}$ (S3) with the reaction temperature.

$\left(10 \% \mathrm{Bi}_{2} \mathrm{O}_{3} / \mathrm{Co}_{3} \mathrm{O}_{4}\right)$ catalyst clearly did not change in the wide reaction window. The steady-state NO conversion reached $90.3 \%$ on $\mathrm{S} 3$ at $250{ }^{\circ} \mathrm{C}$ in the presence and absence of $\mathrm{SO}_{2}$. In contrast, NO conversion decreased from $65.8 \%$ to $35.7 \%$ at $300{ }^{\circ} \mathrm{C}$ on the $\mathrm{Co}_{3} \mathrm{O}_{4}$ support (S1) when 100 ppm $\mathrm{SO}_{2}$ was contained in the feed gas. NO conversions at other reaction temperatures also reduced in the presence of $\mathrm{SO}_{2}$. These results obviously suggested that $10 \% \mathrm{Bi}_{2} \mathrm{O}_{3} / \mathrm{Co}_{3} \mathrm{O}_{4}$ exhibited good resistibility against $\mathrm{SO}_{2}$ that coexists with $\mathrm{NO}$ and $\mathrm{C}_{3} \mathrm{H}_{6}$ in the reaction mixture.

Fig. 9 shows the $\mathrm{SO}_{2}$ durability of $10 \% \mathrm{Bi}_{2} \mathrm{O}_{3} / \mathrm{Co}_{3} \mathrm{O}_{4}$ catalyst with the reaction time at the optimum reaction temperature $200{ }^{\circ} \mathrm{C}$ in the $\mathrm{C}_{3} \mathrm{H}_{6}$-SCR of NO. When NO conversion reached to the maximum (89.3\%), $100 \mathrm{ppm} \mathrm{SO}_{2}$ was added in the reaction system, NO conversion immediately decreased. It was probably due to the competitive adsorption of $\mathrm{NO}$ and $\mathrm{SO}_{2}$ on the active site. $20 \mathrm{~min}$ later, NO conversion reduced to $63.6 \%$. After that,

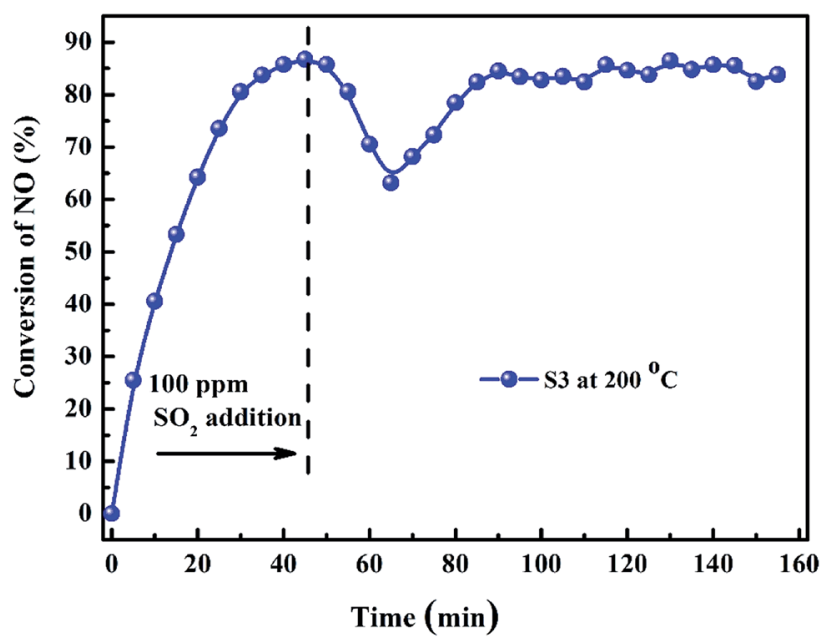

Fig. $9 \mathrm{NO}$ conversion over $10.0 \% \mathrm{Bi}_{2} \mathrm{O}_{3} / \mathrm{CO}_{3} \mathrm{O}_{4}$ (S3) before and after the addition of $\mathrm{SO}_{2}$ (reaction temperature: $200{ }^{\circ} \mathrm{C}$ ).
NO conversion recovered to $85.7 \%$, and maintained at $c a .88 \%$ through the whole reaction period of $90 \mathrm{~min}$. This result further illustrates the outstanding $\mathrm{SO}_{2}$ resistibility of $10 \% \mathrm{Bi}_{2} \mathrm{O}_{3} / \mathrm{Co}_{3} \mathrm{O}_{4}$ in the long time-reaction.

\section{Discussions}

In this study, the deposition of $\mathrm{Bi}_{2} \mathrm{O}_{3}$ with the proper loading amount on $\mathrm{Co}_{3} \mathrm{O}_{4}$ nanoplates enhanced $\mathrm{NO}$ conversion over $\mathrm{Co}_{3} \mathrm{O}_{4}$, especially at low reaction temperature $\left(<200{ }^{\circ} \mathrm{C}\right) .10 .0 \%$ $\mathrm{Bi}_{2} \mathrm{O}_{3} / \mathrm{Co}_{3} \mathrm{O}_{4}$ catalyst also showed the strong resistibility against $\mathrm{SO}_{2}$ in the feed gas. XRD results showed $\mathrm{Bi}_{2} \mathrm{O}_{3}$ could enter the lattice of $\mathrm{Co}_{3} \mathrm{O}_{4}$, and promote the formation of the lattice distortion and structural defect as demonstrated by PL spectra and IR spectra. The $\mathrm{H}_{2}$-TPR and XPS results showed that more $\mathrm{Co}^{3+}$ appeared with the deposition of $\mathrm{Bi}_{2} \mathrm{O}_{3}$. These changes were probably related to the promotive effects of $\mathrm{Bi}_{2} \mathrm{O}_{3}$ in the $\mathrm{C}_{3} \mathrm{H}_{6}$ SCR reaction.

Scheme 1 illustrated the mechanistic investigations for the HC-SCR reactions in the previous literatures. ${ }^{17,36,37}$ According to these findings, the reactants $\left(\mathrm{C}_{3} \mathrm{H}_{6}\right.$, $\mathrm{NO}$ and $\left.\mathrm{NO}_{2}\right)$ are supposed to be first adsorbed on the active sites over the catalyst surface. Subsequently, the adsorbed nitrates formed via NO oxidation by $\mathrm{O}_{2} \cdot \mathrm{C}_{3} \mathrm{H}_{6}$ was also activated to form $\mathrm{C}_{x} \mathrm{H}_{y} \mathrm{O}_{z}$ species such as formate, acetate and so on. As these $\mathrm{C}_{x} \mathrm{H}_{y} \mathrm{O}_{z}$ species become available, nitrates subsequently reacted with them to yield nitrogen-containing organic species, such as NCO species. The final step would be the interaction of NOC intermediates with $\mathrm{NO}_{x}\left(\mathrm{NO}, \mathrm{NO}_{x}\right)$, decomposing into $\mathrm{N}_{2}, \mathrm{CO}_{x}$ and $\mathrm{H}_{2} \mathrm{O}$ as final products. This proposed reaction process reveals the crucial role of $\mathrm{O}_{2}$ in the feed gas and the importance of oxidizing characteristics of the catalyst surface.

In our work, PL and IR results showed that more oxygen vacancies were produced on the $\mathrm{Co}_{3} \mathrm{O}_{4}$ after the doping of $\mathrm{Bi}_{2} \mathrm{O}_{3}$. The vacancy could accelerate the adsorption, activation and diffusion of oxygen, which was suggested to be available for the oxidation reactions involved in HC-SCR. The doped $\mathrm{Bi}_{2} \mathrm{O}_{3}$ also increased the $\mathrm{Co}^{3+}$ concentration on the surface. The richness of $\mathrm{Co}^{3+}$ could promote the adsorption and activation of $\mathrm{NO}$ and (or) $\mathrm{C}_{3} \mathrm{H}_{6}$. What is more is the mild oxidizing characteristics of

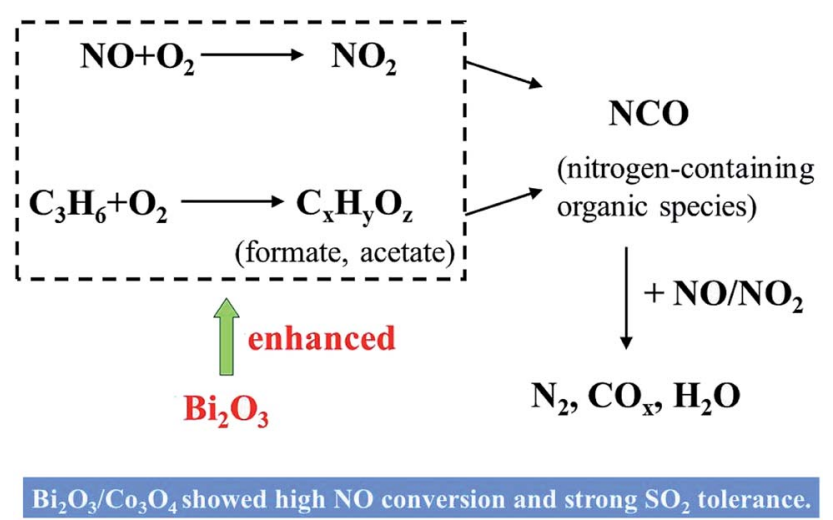

Scheme 1 The promotive effects of $\mathrm{Bi}_{2} \mathrm{O}_{3}$ on $\mathrm{NO}$ reduction by propene over $\mathrm{CO}_{3} \mathrm{O}_{4}$ catalyst. 
bismuth oxide in the selective oxidation and ammoxidation of propene to acrolein and acrylonitrile. It will accelerate the formation of $\mathrm{C}_{x} \mathrm{H}_{y} \mathrm{O}_{z}$ species. In short, the addition of $\mathrm{Bi}_{2} \mathrm{O}_{3}$ into the $\mathrm{Co}_{3} \mathrm{O}_{4}$ in the present study probably influenced the oxidation process in the $\mathrm{C}_{3} \mathrm{H}_{6}$-SCR reaction, favored the activation of $\mathrm{C}_{3} \mathrm{H}_{6}$ and NO, and then enhanced the following NCO intermediate formation and its decomposition with reaction with $\mathrm{NO}_{x}$ to $\mathrm{N}_{2}$.

About poisoning $\mathrm{HC}-\mathrm{SCR}$ catalyst with $\mathrm{SO}_{2}$, the previous studies reported that the suppression effect of $\mathrm{SO}_{2}$ on the SCR catalyst could attributed to the formation of sulphate on the catalyst. ${ }^{38}$ The presence of surface $\mathrm{SO}_{4}{ }^{2-}$ groups blocked the formation of nitrate and decreased the amount of adsorbed nitrates. Thus it hindered the transformation of NOC species and decreased the catalytic activity. In our work, the presence of $100 \mathrm{ppm} \mathrm{SO}_{2}$ in the feed gas decreased the $\mathrm{NO}$ conversion over $\mathrm{Co}_{3} \mathrm{O}_{4}$ catalyst, while the $\mathrm{SO}_{2}$ tolerance of $\mathrm{Bi}_{2} \mathrm{O}_{3} / \mathrm{Co}_{3} \mathrm{O}_{4}$ was strong. $10 \% \mathrm{Bi}_{2} \mathrm{O}_{3} / \mathrm{Co}_{3} \mathrm{O}_{4}$ showed the good stability when $\mathrm{SO}_{2}$ was co-fed in the mixture gas during $90 \mathrm{~min}$. This promotive role of $\mathrm{Bi}_{2} \mathrm{O}_{3}$ on the resistibility against $\mathrm{SO}_{2}$ also could be explained by the oxidizing properties of $10 \% \mathrm{Bi}_{2} \mathrm{O}_{3} / \mathrm{Co}_{3} \mathrm{O}_{4}$. The addition of $\mathrm{Bi}_{2} \mathrm{O}_{3}$ into $\mathrm{Co}_{3} \mathrm{O}_{4}$ promoted the partial oxidation of propene activation of $\mathrm{C}_{3} \mathrm{H}_{6}$. The activation of $\mathrm{C}_{3} \mathrm{H}_{6}$ over $10 \%$ $\mathrm{Bi}_{2} \mathrm{O}_{3} / \mathrm{Co}_{3} \mathrm{O}_{4}$ seems more competitive in the compassion with the oxidization of $\mathrm{SO}_{2}$ to form surface sulfate. Subsequently, it is suggested that the addition of $\mathrm{Bi}_{2} \mathrm{O}_{3}$ into $\mathrm{Co}_{3} \mathrm{O}_{4}$ is one appropriate method for improving the $\mathrm{SO}_{2}$ resistance of $\mathrm{Co}_{3} \mathrm{O}_{4}$.

\section{Conclusions}

The optimum $\mathrm{Bi}_{2} \mathrm{O}_{3}$ loading on the $\mathrm{Co}_{3} \mathrm{O}_{4}$ nanoplates for the $\mathrm{C}_{3} \mathrm{H}_{6}$-SCR of $\mathrm{NO}$ was about $10 \%$, giving the best catalytic activity, especially at low reaction temperature, as well as the strongest $\mathrm{SO}_{2}$ tolerance. The decoration of moderate $\mathrm{Bi}_{2} \mathrm{O}_{3}$ on $\mathrm{Co}_{3} \mathrm{O}_{4}$ influenced the oxidation state of $\mathrm{Co}_{3} \mathrm{O}_{4}$, facilitate the surface oxygen mobility and the partial oxidation of propene involved in the $\mathrm{C}_{3} \mathrm{H}_{6}$-SCR reaction. Therefore, the combination of $\mathrm{Co}_{3} \mathrm{O}_{4}$ with $\mathrm{Bi}_{2} \mathrm{O}_{3}$ is more active than $\mathrm{Co}_{3} \mathrm{O}_{4}$. The addition of $100 \mathrm{ppm} \mathrm{SO}_{2}$ to the feed hardly affected the catalytic performance of $10 \% \mathrm{Bi}_{2} \mathrm{O}_{3} / \mathrm{Co}_{3} \mathrm{O}_{4}$.

\section{Conflicts of interest}

There are no conflict to declare.

\section{Acknowledgements}

This work was supported by the China National Natural Science Foundation (No. 51178360) and Hubei Superior and Distinctive Discipline Group of "Mechatronics and Automobiles" (XKQ2019058).

\section{References}

1 C. R. Thomas, J. A. Pihl, M. J. Lance, T. J. Toops, J. E. Parks and J. Lauterbach, Effects of four-mode hydrothermal aging on three-way catalysts for passive selective catalytic reduction to control emissions from lean-burn gasoline engine, Appl. Catal., B, 2019, 244, 284-294.

2 Y. Rui, M. Ming, Z. Jing, L. Zheng, T. Hu and X. Li, A noblemetal-free SCR-LNT coupled catalytic system used for highconcentration $\mathrm{NO}_{x}$ reduction under lean-burn condition, Catal. Today, 2018, 347-356.

3 J. A. Lupescu, J. W. Schwank, G. B. Fisher, J. Hangas, S. L. Peczonczyk and W. A. Paxton, Pd model catalysts: effect of air pulse length during redox aging on $\mathrm{Pd}$ redispersion, Appl. Catal., B, 2018, 223, 76-90.

$4 \mathrm{Y}$. Hu and K. Griffiths, Selective Catalytic Reduction of NO by Hydrocarbons on a Stepped Pt Surface: Influence of $\mathrm{SO}_{2}$ and $\mathrm{O}_{2}$, J. Phys. Chem. C, 2015, 119, 19789-19801.

5 M. Khosravi, C. Sola, A. Abedi, R. E. Hayes, W. S. Epling and M. Votsmeier, Oxidation and selective catalytic reduction of NO by propene over Pt and Pt:Pd diesel oxidation catalysts, Appl. Catal., B, 2014, 147, 264-274.

6 P. Miquel, P. Granger, N. Jagtap, S. Umbarkar, M. Dongare and C. Dujardin, NO reduction under diesel exhaust conditions over $\mathrm{Au} / \mathrm{Al}_{2} \mathrm{O}_{3}$ prepared by depositionprecipitation method, J. Mol. Catal. A: Chem., 2010, 322, 90-97.

7 X. Wang, N. Maeda and A. Baiker, Synergistic Effects of Au and $\mathrm{FeO}_{x}$ Nanocomposites in Catalytic NO Reduction with CO, ACS Catal., 2016, 6, 7898-7906.

8 P. A. Kumar, M. P. Reddy, B. Hyun-Sook and H. H. Phil, Influence of $\mathrm{Mg}$ Addition on the Catalytic Activity of Alumina Supported $\mathrm{Ag}$ for $\mathrm{C}_{3} \mathrm{H}_{6}$-SCR of NO, Catal. Lett., 2009, 131, 85-97.

9 A. Musi, P. Massiani, D. Brouri, J.-M. Trichard and P. Da Costa, On the Characterisation of Silver Species for SCR of $\mathrm{NO}_{x}$ with Ethanol, Catal. Lett., 2008, 128, 25-30.

10 P. Namkhang and P. Kongkachuichay, Synthesis of CopperBased Nanostructured Catalysts on $\mathrm{SiO}_{2}-\mathrm{Al}_{2} \mathrm{O}_{3}, \mathrm{SiO}_{2}-\mathrm{TiO}_{2}$, and $\mathrm{SiO}_{2}-\mathrm{ZrO}_{2}$ Supports for NO Reduction, J. Nanosci. Nanotechnol., 2015, 15, 5410-5417.

11 J. Liu, X. Li, Q. Zhao, D. Zhang and P. Ndokoye, The selective catalytic reduction of $\mathrm{NO}$ with propene over $\mathrm{Cu}$-supported Ti-Ce mixed oxide catalysts: promotional effect of ceria, $J$. Mol. Catal. A: Chem., 2013, 378, 115-123.

$12 \mathrm{Z}$. Liu, J. Li and J. Hao, Selective catalytic reduction of $\mathrm{NO}_{x}$ with propene over $\mathrm{SnO}_{2} / \mathrm{Al}_{2} \mathrm{O}_{3}$ catalyst, Chem. Eng. J., 2010, 165, 420-425.

13 M. Chen, J. Yang, Y. Liu, W. Li, J. Fan, X. Ran, W. Teng, Y. Sun, W.-x. Zhang, G. Li, S. X. Dou and D. Zhao, TiO interpenetrating networks decorated with $\mathrm{SnO}_{2}$ nanocrystals: enhanced activity of selective catalytic reduction of NO with $\mathrm{NH}_{3}$, J. Mater. Chem. A, 2015, 3, 1405-1409.

14 L. Zhang, L. Li, Y. Cao, Y. Xiong, S. Wu, J. Sun, C. Tang, F. Gao and L. Dong, Promotional effect of doping $\mathrm{SnO}_{2}$ into $\mathrm{TiO}_{2}$ over a $\mathrm{CeO}_{2} / \mathrm{TiO}_{2}$ catalyst for selective catalytic reduction of $\mathrm{NO}$ by $\mathrm{NH}_{3}$, Catal. Sci. Technol., 2015, 5, 21882196.

15 D. Pietrogiacomi, M. C. Campa, L. R. Carbone, S. Tuti and M. Occhiuzzi, $\mathrm{N}_{2} \mathrm{O}$ decomposition on $\mathrm{CoO}_{x}, \mathrm{CuO}_{x}, \mathrm{FeO}_{x}$ or $\mathrm{MnO}_{x}$ supported on $\mathrm{ZrO}_{2}$ : the effect of zirconia doping 
with sulfates or $\mathrm{K}^{+}$on catalytic activity, Appl. Catal., B, 2016, 187, 218-227.

16 Y. Yu, Q. Zhong, W. Cai and J. Ding, Promotional effect of Ndoped $\mathrm{CeO}_{2}$ supported $\mathrm{CoO}_{x}$ catalysts with enhanced catalytic activity on NO oxidation, J. Mol. Catal. A: Chem., 2015, 398, 344-352.

17 F. Huang, W. Hu, J. Chen, Y. Wu, P. Qu, S. Yuan, L. Zhong and Y. Chen, Insight into Enhancement of NO Reduction with Methane by Multifunctional Catalysis over a Mixture of Ce/HZSM-5 and $\mathrm{CoO}_{x}$ in Excess of Oxygen, Ind. Eng. Chem. Res., 2018, 57, 13312-13317.

18 L. Zhang, X. Yao, Y. Lu, C. Sun, C. Tang, F. Gao and L. Dong, Effect of precursors on the structure and activity of $\mathrm{CuO}$ $\mathrm{CoO}_{x} /$ gamma- $\mathrm{Al}_{2} \mathrm{O}_{3}$ catalysts for $\mathrm{NO}$ reduction by $\mathrm{CO}, J$. Colloid Interface Sci., 2018, 509, 334-345.

19 B. Dou, G. Lv, C. Wang, Q. Hao and K. Hui, Cerium doped copper/ZSM-5 catalysts used for the selective catalytic reduction of nitrogen oxide with ammonia, Chem. Eng. J., 2015, 270, 549-556.

20 M. Sakmeche, A. Belhakem, R. Kessas and S. A. Ghomari, Effect of parameters on NO reduction by methane in presence of excess $\mathrm{O}_{2}$ and functionalized AlMCM-41 as catalysts, J. Taiwan Inst. Chem. Eng., 2017, 80, 333-341.

21 F. Bin, C. Song, G. Lv, J. Song, X. Cao, H. Pang and K. Wang, Structural Characterization and Selective Catalytic Reduction of Nitrogen Oxides with Ammonia: A Comparison between Co/ZSM-5 and Co/SBA-15, J. Phys. Chem. C, 2012, 116, 26262-26274.

22 D. Pietrogiacomi, A. Magliano, P. Ciambelli, D. Sannino, M. C. Campa and V. Indovina, The effect of sulphation on the catalytic activity of $\mathrm{CoO}_{x} / \mathrm{ZrO}_{2}$ for NO reduction with $\mathrm{NH}_{3}$ in the presence of $\mathrm{O}_{2}$, Appl. Catal., B, 2009, 89, 33-40.

23 A. Cabot, A. Marsal, J. Arbiol and J. R. Morante, $\mathrm{Bi}_{2} \mathrm{O}_{3}$ as a selective sensing material for NO detection, Sens. Actuators, B, 2004, 99, 74-89.

24 J. F. Brazdil, M. A. Toft, S. S. Y. Lin, S. T. McKenna, G. Zajac, J. A. Kaduk and J. T. Golab, Characterization of bismuthcerium-molybdate selective propylene ammoxidation catalysts, Appl. Catal., A, 2015, 495, 115-123.

25 Y.-H. Lei and Z.-X. Chen, Theoretical study of propene oxidation on $\mathrm{Bi}_{2} \mathrm{O}_{3}$ surfaces, Sci. China: Chem., 2015, 58, 593-600.

26 R. B. Licht and A. T. Bell, A DFT Investigation of the Mechanism of Propene Ammoxidation over $\alpha$-Bismuth Molybdate, ACS Catal., 2016, 7, 161-176.

27 S. Kumar Megarajan, S. Rayalu, Y. Teraoka and N. Labhsetwar, High NO oxidation catalytic activity on non-noble metal based cobalt-ceria catalyst for diesel soot oxidation, J. Mol. Catal. A: Chem., 2014, 385, 112-118.
28 J.-W. Shi, G. Gao, Z. Fan, C. Gao, B. Wang, Y. Wang, Z. Li, C. He and C. Niu, $\mathrm{Ni}_{y} \mathrm{Co}_{1-y} \mathrm{Mn}_{2} \mathrm{O}_{x}$ microspheres for the selective catalytic reduction of $\mathrm{NO}_{x}$ with $\mathrm{NH}_{3}$ : the synergetic effects between $\mathrm{Ni}$ and Co for improving lowtemperature catalytic performance, Appl. Catal., A, 2018, 560, 1-11.

29 D. Wang, Q. Wang and T. Wang, Morphology-controllable synthesis of cobalt oxalates and their conversion to mesoporous $\mathrm{Co}_{3} \mathrm{O}_{4}$ nanostructures for application in supercapacitors, Inorg. Chem., 2011, 50, 6482-6492.

30 J.-W. Shi, Z. Fan, C. Gao, G. Gao, B. Wang, Y. Wang, C. He and C. Niu, Mn-Co Mixed Oxide Nanosheets Vertically Anchored on $\mathrm{H}_{2} \mathrm{Ti}_{3} \mathrm{O}_{7}$ Nanowires: Full Exposure of Active Components Results in Significantly Enhanced Catalytic Performance, ChemCatChem, 2018, 10, 2833-2844.

31 Z. Zhu, G. Lu, Z. Zhang, Y. Guo, Y. Guo and Y. Wang, Highly Active and Stable $\mathrm{Co}_{3} \mathrm{O}_{4} / \mathrm{ZSM}-5$ Catalyst for Propane Oxidation: Effect of the Preparation Method, ACS Catal., 2013, 3, 1154-1164.

32 H. Hu, S. Cai, H. Li, L. Huang, L. Shi and D. Zhang, In Situ DRIFTs Investigation of the Low-Temperature Reaction Mechanism over Mn-Doped $\mathrm{Co}_{3} \mathrm{O}_{4}$ for the Selective Catalytic Reduction of $\mathrm{NO}_{\mathrm{x}}$ with $\mathrm{NH}_{3}, J$. Phys. Chem. C, 2015, 119, 22924-22933.

33 G. Gao, J.-W. Shi, Z. Fan, C. Gao and C. Niu, $\mathrm{MnM}_{2} \mathrm{O}_{4}$ microspheres $(\mathrm{M}=\mathrm{Co}, \mathrm{Cu}, \mathrm{Ni})$ for selective catalytic reduction of $\mathrm{NO}$ with $\mathrm{NH}_{3}$ : comparative study on catalytic activity and reaction mechanism via in situ diffuse reflectance infrared Fourier transform spectroscopy, Chem. Eng. J., 2017, 325, 91-100.

34 L. Wang, S. Zhang, Y. Zhu, A. Patlolla, J. Shan, H. Yoshida, S. Takeda, A. I. Frenkel and F. Tao, Catalysis and In Situ Studies of $\mathrm{Rh}_{1} / \mathrm{Co}_{3} \mathrm{O}_{4}$ Nanorods in Reduction of NO with $\mathrm{H}_{2}$, ACS Catal., 2013, 3, 1011-1019.

35 Y. Lou, L. Wang, Z. Zhao, Y. Zhang, Z. Zhang, G. Lu, Y. Guo and Y. Guo, Low-temperature $\mathrm{CO}$ oxidation over $\mathrm{Co}_{3} \mathrm{O}_{4}-$ based catalysts: significant promoting effect of $\mathrm{Bi}_{2} \mathrm{O}_{3}$ on $\mathrm{Co}_{3} \mathrm{O}_{4}$ catalyst, Appl. Catal., B, 2014, 146, 43-49.

36 X. Chen, X. Yang, A. Zhu, C. T. Au and C. Shi, In situ DRIFTS study during $\mathrm{C}_{2} \mathrm{H}_{4}$-SCR of NO over Co-ZSM-5, J. Mol. Catal. A: Chem., 2009, 312, 31-39.

37 M. C. Campa, D. Pietrogiacomi, C. Scarfiello, L. R. Carbone and M. Occhiuzzi, $\mathrm{CoO}_{x}$ and $\mathrm{FeO}_{x}$ supported on $\mathrm{ZrO}_{2}$ for the simultaneous abatement of $\mathrm{NO}_{x}$ and $\mathrm{N}_{2} \mathrm{O}$ with $\mathrm{C}_{3} \mathrm{H}_{6}$ in the presence of $\mathrm{O}_{2}$, Appl. Catal., B, 2019, 240, 367-372.

38 X. Xiao, S. Xiong, Y. Shi, W. Shan and S. Yang, Effect of $\mathrm{H}_{2} \mathrm{O}$ and $\mathrm{SO}_{2}$ on the Selective Catalytic Reduction of $\mathrm{NO}$ with $\mathrm{NH}_{3}$ Over Ce/ $/ \mathrm{TiO}_{2}$ Catalyst: Mechanism and Kinetic Study, J. Phys. Chem. C, 2016, 120, 1066-1076. 